\title{
RNA Polymerase II Elongation Factor ELL
}

National Cancer Institute

\section{Source}

National Cancer Institute. RNA Polymerase I/ Elongation Factor ELL. NCI Thesaurus.

Code C97518.

RNA polymerase II elong ation factor ELL ( $621 \mathrm{aa}, \sim 68 \mathrm{kDa}$ ) is encoded by the human ELL gene. This protein is involved in the positive regulation of RNA synthesis. 